\title{
Providing a framework for knowledge sharing in knowledge-based organizations according to social capital indicators
}

Saeed Ghorbani ${ }^{*}$, Shayan Naghdi Khanachah ${ }^{2}$

Malek Ashtar University of Technology, Tehran, Iran ${ }^{1,2}$

sgh14@yahoo.com ${ }^{1 *}$, shayan.en24@gmail.com ${ }^{2}$

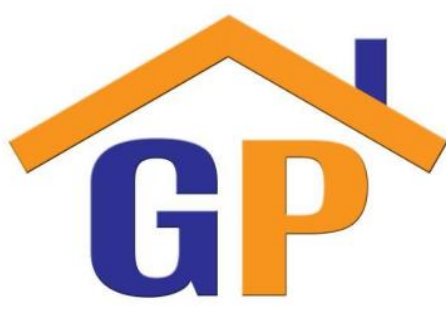

Article History

Received on 14 March 2021

$1^{\text {st }}$ Revision on 23 March 2021

$2^{\text {nd }}$ Revision on 24 March 2021

Accepted on 25 March 2021

\begin{abstract}
Purpose: This study aimed to provide a framework for examining knowledge sharing from the perspective of social capital in knowledge-based organizations. For this purpose, the social capital and knowledge sharing literature has been reviewed and appropriate dimensions and components have been selected for use in the proposed framework.
\end{abstract}

Research methodology: The number of experts participating in this study was 12. Kendall's W Ranks is a statistical index for assessing the degree of agreement in a group. This statistical index, which is related to non-parametric statistics, is used to assess the degree to which a number of evaluators agree on the ranking of several factors.

Result: This research's proposed framework shows that the main bottleneck in the knowledge sharing process is the sender. Numerous factors affect the motivation, quantity and quality of knowledge shared by him. The proposed conceptual model shows the factors in the field of social capital well. This means that the organization's managers should pay special attention to people with knowledge to activate the process of knowledge sharing in the organization as a driving force.

Limitations: This research only described knowledge-based organizations.

Contribution: The proposed conceptual framework makes a good distinction between formal and informal knowledge-sharing channels in a knowledge-based organization. Formal channels are controlled and manageable channels. Although the main burden of knowledge sharing in organizations lies with informal channels, the more managers can shift the organization's knowledge to formal channels, the more they can manage the process. This is a part of the job that social capital, in particular, helps to achieve. The proposed framework discusses the acceptance of the use of formal frameworks.

Keywords: Social capital, Knowledge management, Knowledge sharing, Expertise method

How to cite: Ghorbani, S., \& Naghdi Khanachah, S. N. (2020). Providing a framework for knowledge sharing in knowledge-based organizations according to social capital indicators. Annals of Management and Organization Research, 1(4), 271-284.

\section{Introduction}

Research on knowledge transfer and sharing initially focused only on information and communication technologies. Researchers believed that the better an organization could implement these technologies, the more knowledge transfer and benefits it would provide (Argote \& Fahrenkopf, 2016). Subsequent empirical observations did not confirm this notion and it was stated that the motivating factor for knowledge sharing is more important, and information and communication systems related to 
knowledge management to succeed in achieving their goals must create appropriate social capital for the organization. Social capital makes and shares knowledge (Paulin \& Suneson, 2015).

Other research in this area has concluded that some barriers such as lack of absorption capacity, ambiguity in causal relationships and difficulty in communicating between source and recipient of knowledge over other barriers related to motivation in knowledge sharing (such as loss of superiority to Traditionally considered to be the main barriers to knowledge sharing), they are more prominent and dominant (Paulin \& Suneson, 2015). But in any case, all of the above - all of which are considered more important than the issue of information and communication technology. They have social roots and can be viewed from the perspective of social capital theories. Thus, although having information and communication technology infrastructure is a necessary condition for knowledge transfer, creating the necessary conditions for individual participation and knowledge sharing, which has been raised in the social and content dimensions of organizations, is a sufficient condition for the knowledge transfer process. This is true not only of the knowledge sharing process but also of all knowledge management processes in organizations (Rosser, 2005).

On the other hand, it should be noted that although it is generally accepted that knowledge exists in individuals, this does not mean that knowledge is independent of content and contextual elements. The application and sharing of knowledge always take place in the shadow of the elements of specific physical contexts and the mental models of the people involved in this transfer (Raza \& Awang, 2020). That is why knowledge can be recognized by the fact that it is inherently social and content (Dabic et al., 2020). Therefore, the process of knowledge sharing between individuals is contingent and depends on their social interactions and exchanges. As a result, the main focus on the subject of the process and knowledge sharing determinants is on interpersonal relationships. As it turns out, social capital plays a key role in knowledge sharing in organizations (and any type of social network in general) (Oliveira, Curado, Balle, \& Kianto, 2020). Based on theoretical knowledge and available empirical evidence, this paper aimed to provide a conceptual framework to illustrate how social capital affects knowledge-based organizations' knowledge management. For this purpose, in the second part of the literature, the subject of social capital and knowledge sharing is reviewed and a conceptual framework is proposed based on the study of literature. The third section describes the methodology used to evaluate and validate this conceptual framework - the expert method. In the fourth section, the results of the implementation of the expertise method and brainstorming are stated, and at the end, summary and suggestions for managers as well as future research will be done.

\section{Literature review}

\subsection{Social capital}

However, there is a general consensus that social capital includes the structure and content of social networks. According to different approaches to this concept, different definitions have been formed. According to their focus, these definitions differ whether they have paid attention to social capital's nature or its sources or results (Levasseur, Richard, Gauvin, \& Raymond, 2010). In addition, these differences can be seen in the type of relationships under study. Some existing definitions introduce social capital in the form of an integrated entity that is formed in social relations between individuals and makes it possible for members of the social network to achieve specific goals (Rass, Dumbach, Danzinger, Bullinger, \& Moeslein, 2013). Others emphasize the differences in the nature of concepts integrated under the heading of "social capital." When looking at social capital, this emphasis is important because some researchers consider it to be very simple and equivalent to "trust", and these definitions try to eliminate such a view. The third section distinguishes between what is considered as social capital for individuals and what makes it possible to achieve individual goals, and what exists in the organization as a whole and facilitates the achievement of organizational goals(Ployhart, Nyberg, Reilly, \& Maltarich, 2014). attention to this difference helps to consider the path of transforming individual social capital into an organization and not to be overlooked because the two are considered the same. This set of definitions is a subset of a larger set of definitions that place different social capital levels. These levels start with the individual and reach a group, organizational unit, organization, interorganizational/industrial, and even a community (Nhon, 2020).

In this article, according to the above set of definitions and due to the limited level of review to the organization, social capital is defined as follows: 
"Social capital is a set of social assets such as trust, common norms and values, mutual understanding, etc. that are created as a result of social relations between members of the organization and are jointly owned by individuals and the realization of organizational goals and implementation of joint activities for the mission. "It facilitates the organization."

Various researchers have introduced numerous dimensions and components for social capital. Nahapiet and Ghoshal provide the most famous category. These two researchers have categorized social capital components into three categories (Bapuji \& Crossan, 2005): structural, relational, and cognitive. A large number of researchers later applied this triple classification. The two researchers defined the above dimensions as follows:

- Structural dimension: the plan or general communication pattern between operators (individuals or organizational units). In other words, knowing who you have access to and how you have access. For example, the presence or absence of a relationship between operators, a network configuration or its morphology measured by criteria such as density, connectivity, and hierarchy, and what Weiden-Wolf and Ginman call an appropriate social organization in the sense of existence (Paulin \& Suneson, 2015). It is a network created for a specific purpose but can be used for another purpose. Relationship dimension (Nesheim \& Gressgård, 2014): The structural dimension deals only with the relationship, but the type of relationship (such as friendship or respect) is an issue that arises in the relationship dimension. In fact, this dimension deals with assets that are created and strengthened by relationships. The nature of relationships in organizations is very different. These relationships can be about friendship, work issues or getting guidance. What flows in these relationships can be resources, information, knowledge, or kindness. These relationships can be face-to-face or electronic, and they can also be one-dimensional or multidimensional. These and dozens of other issues make the nature of relationships in organizations very diverse (Nesheim \& Gressgård, 2014). The nature and type of relationships have a significant impact on practice and are needed to perform various tasks in organizations. Despite this diversity, we can divide relationships in organizations into formal and informal. Formal relationships are expressed in job descriptions and organizational charts, and informal relationships are formed and help people, regardless of individuals' rank and position (Duan, Wang, \& Zhou, 2020).

- Cognitive dimension: refers to resources that create a common representation or representation, a common interpretation, and a system of common meanings among network members. This dimension's most important components are common language and symbols and common stories (Zahedi \& Khanachah, 2019). These stories are a platform for transmitting the common history and values of an organization to new people. Some researchers have also proposed common values and norms as components of the cognitive dimension, which differs from Nahapiet and Ghoshal's views. As mentioned, the last two researchers have categorized these two components as dimensions of social capital relations (Zahedi \& Khanachah, 2020). Given what is presented in the cognitive dimension definition, it seems that common norms and values should be considered components of the cognitive dimension because they are more similar to other components introduced in this dimension (Duan et al., 2020).

Although subsequent research has used other dimensions and components for social capital, a closer look at these dimensions and components shows that the theory of the three dimensions of Nehpite and Gushal remains a comprehensive theory as well as other theories. For this reason, in this research, the dimensions introduced by these two researchers are used as the dimensions of social capital.

\subsection{Knowledge sharing}

The role of knowledge in the information science and management literature has been widely discussed. The new economy, called the knowledge-based economy, is said to create value with a different logic than the old industrial economy. Specific characteristics of knowledge, such as being a public good and indefinitely reproducible, have made it a key economic resource and the main source of competitive advantage, and its use has increased efficiency, higher leverage, increased organizational value, and promotion (Zahedi \& Naghdi Khanachah, 2019). Be innovative. Thus, traditional production factors (such as land, labor, and capital) are of secondary importance.

"Knowledge", despite its great importance, has problems such as intangibility and the difficulty of preserving its value. Most organizations have valuable knowledge about their products, processes, 
management and technologies. But most of them do not use this knowledge as much as they should to take full advantage of it (Kim \& Park, 2017). Therefore, organizations can use "knowledge" as a source of competitive advantage when they can create or acquire new knowledge, transfer it to the appropriate components of the organization, interpret this knowledge and combine it with the current knowledge of the organization and Use it to achieve better performance (Stone et al., 2017). This is the concept that has been introduced as "knowledge management" in the literature. Knowledge management is nothing more than delivering the right information to the right person at the right time (Yang, 2017). Knowledge management is defined as the process of accumulating and creating knowledge and facilitating its sharing in a way that enables its effective application throughout the organization. Knowledge management consists of four main processes. It is the first process of knowledge creation that includes all activities related to discovering new knowledge (Hajro, Gibson, \& Pudelko, 2017). The second process is knowledge capture, which involves exploring, organizing, and continually packing knowledge after it is created. Knowledge development is the third process and is to present knowledge in an easily accessible and transferable way. The last process is the transfer of knowledge, which involves sending knowledge by one person or group to another person or group and absorbing that knowledge by the recipient (Wang et al., 2017).

Among the various processes that have been proposed in the concept of knowledge management, the process of knowledge sharing has been introduced as the most difficult. On the other hand, the ability to effectively transfer and share knowledge has been introduced as a critical factor in achieving organizational competitiveness. Success in this century is related to the amount of knowledge that people in the organization have and the rate at which they share and learn this knowledge (P. Wang et al., 2016). Experimental research has shown that the rate of knowledge exchange in the organization has a positive relationship with innovating and higher productivity levels. In addition, researchers believe that organizations are more productive that can transfer knowledge from one organizational unit to another. In fact, when new knowledge enters a part of the organization or is created in it, it must be transferred to other parts, otherwise, it will have very little impact on the organization. Due to this strong relationship between knowledge sharing in the organization and creating a competitive advantage for it, it is not unexpected that Moo et al. Have reviewed various articles and stated that knowledge transfer and knowledge flow has been one of the active areas of research in different years (Jayaram \& Pathak, $\underline{2013)}$.

There are very similar definitions of knowledge sharing. These definitions have in common the transfer of knowledge from one person or group to another person or group. Whether this interaction is voluntary or mandatory or whether it is to create new knowledge or not, knowledge sharing within the organization can be simply introduced, as defined by Hsu in (Majchrzak, Faraj, Kane, \& Azad, 2013), "Knowledge sharing is the transfer or dissemination of various types of knowledge from one person or group to another person or group within the organization." Previous research in the field of social capital and knowledge sharing has focused more on the sender of knowledge. In contrast, the whole process of knowledge sharing involves the sender, communication channels, and receiver of knowledge. According to this approach and based on the view of Menu and Walker (2006), this paper uses a process approach to knowledge sharing (Jameson, Ferrell, Kelly, Walker, \& Ryan, 2006). This approach makes it possible to clearly identify the points of impact of social capital on the knowledge sharing process.

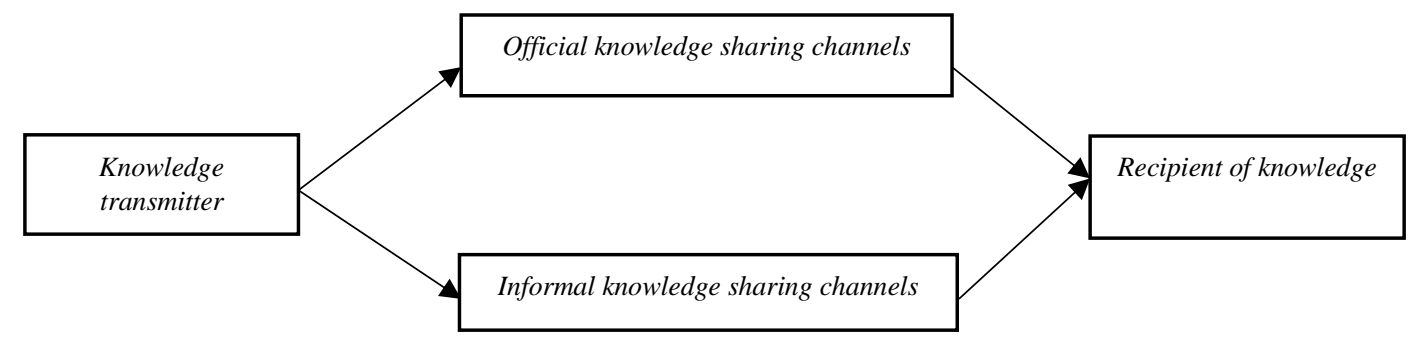

Figure 1. Knowledge sharing process model (Maqsood, Walker, \& Finegan, 2007).

\subsection{The relationship between social capital and knowledge sharing}

\subsubsection{Literature on the structural relationship between social capital and knowledge sharing}

The structural dimension of social capital provides individuals with access to knowledge. Social network structures can help solve the question of why one type of information or knowledge is disseminated within the network but not another type of knowledge. Smedlund (2006) has tried to provide a clear 
answer to this question by introducing three types of special structures for different types of knowledge (Smedlund, 2006). This researcher believes that the best structure for sharing and utilizing explicit knowledge is centralized structure, hidden knowledge distributed structure, and potential knowledge, decentralized structure (Fang \& Chiu, 2010).

The need for knowledge sharing among experts in various fields to create new knowledge in the development of new products has been emphasized by Brauner \& Becker (2006) which confirms the appropriateness of a decentralized structure for sharing and applying potential knowledge to create new knowledge. In contrast, Ahuja in Smedlund (2006) concluded in his research that both direct and indirect links positively affect innovation, but structural cavities have a negative effect. Simmie (2005) has also emphasized the importance of the number of links and their focus on innovation and faster growth. In fact, this research seems to suggest that the centralized structure is potentially useful for knowledge (Simmie, 2005). The above structures are potentially more useful for knowledge sharing and require further investigation and empirical work (Isaksen \& Jakobsen, 2017).

\subsubsection{Relationship dimension literature of social capital and knowledge sharing}

The relationship of social capital affects the motivation of individuals to combine and share knowledge. It is believed that investing in social values based on reciprocity, trust and respect can lead to long-term benefits for the organization, including organizational satisfaction and innovation. It is believed that these benefits are rooted in better knowledge sharing, lower transaction costs due to the strong spirit of communication and coordination, and more relevant and connected actions in the organization (Moustaghfir et al., 2013). Some empirical research has failed to show a direct relationship between trust and creating a positive attitude towards knowledge sharing as well as creating a culture of knowledge sharing in the organization. Some researchers have concluded that trust is not a determinant of knowledge sharing unless Risk conditions govern the relationship (Alejandro, Yang, Alejandro, \& Boles, 2011). Of course, it should be noted that lack of trust will have a negative impact on knowledge sharing. However, there are numerous studies that have theoretically emphasized the importance of trust in knowledge sharing (Mäkelä, Andersson, \& Seppälä, 2012).

Some researchers believe that people who communicate regularly with others or have stronger emotional attachments are more likely to share their knowledge. In their experimental work, (De Clercq, Dimov, \& Thongpapanl, 2013) found a positive relationship between the degree of attachment in relationships and the level of desire and motivation to share knowledge. Research has shown that people share information more with their friends than those who are not friends. Ingram and Roberts in (Buonincontri, Morvillo, Okumus, \& van Niekerk, 2017) found that hotel managers in Sydney concluded that managers who were in a dense network of intermediary friendships passed on their knowledge of customers and successful experiences to each other, and this led to profitability. And their work has been done. Van den Huff and De Rider in (Cleveland \& Ellis, 2015) also concluded that the atmosphere of communication has a positive effect on the willingness of individuals to share their knowledge with others .

\subsubsection{Literature on the cognitive dimension of social capital and knowledge sharing}

The norms and values embedded in social capital create the view of Fadel \& Durcikova (2014), motivation and desire to participate in knowledge exchange (Fadel \& Durcikova, 2014). Shared values and norms, shared understanding and trust (the latter of which is a component of the relational dimension of social capital) contribute to the unconditional knowledge sharing in the organization. (Pyo et al., 2012) have reviewed various studies and reported the positive effect of group norms and identity on knowledge sharing. Common goals also have a positive effect on people's attitudes toward knowledge sharing and create a culture of knowledge sharing in the organization (Majchrzak et al., 2013).

Ideally, the result of the exchange of information and knowledge among group members is greater understanding, change in attitudes and situations, collective problem solving, and shared interpretation of events that make people more connected within the social network. Mutual understanding between network members also promotes the sharing of more complex forms of knowledge. Here we must address the issue of accepting formal frameworks for knowledge sharing in the organization as one of the important components of the cognitive dimension of social capital. Weiden Wolf and Ginman in Majchrzak et al., (2013) briefly introduce four categories of challenges in understanding, organizing, and managing knowledge. These challenges include: 
(1) Technical challenge: This challenge is more about designing information and human systems to organize information, and of course to coordinate the two systems with each other.

(2) Management challenge: This challenge is about creating the right environment for knowledge sharing.

(3) Individual challenge: This challenge is about people as those who have knowledge in their minds. In this section, having an open mind to accept the ideas of others is considered more.

(4) Social Challenge: This challenge is about the development of communities for knowledge sharing and especially in relation to social capital in the organization.

Some research has shown that in work environments where tasks are performed routinely, the formal structure for knowledge sharing and acceptance of these structures (as a cognitive component of social capital that increases the efficiency of formal knowledge sharing channels in organizations) Is of great importance and in the environments in which experts work, the dimensions of social capital relations are decisive in knowledge sharing (Vera-Mun ${ }^{\sim} \mathrm{oz}, \mathrm{Ho}, \&$ Chow, 2006).

\subsection{Providing a conceptual framework}

On the one hand, this study, in continuation of previous researches, takes the dimensions and components of social capital as well as the dimensions and components of knowledge sharing (in the form of a knowledge sharing process model) from other researches and on the other hand, the connections between these two areas. According to the literature review, the concepts were compiled in the form of a preliminary list and their relationship with each other was also identified (King \& Marks $\mathrm{Jr}$, 2008). The cases were then provided to 12 technical experts familiar with the concepts of knowledge management and intellectual capital to comment on the communication and classification of concepts. Finally, it was finally approved as table number one and was conceptualized in the form of a conceptual framework. The survey surveyed every 12 people. Based on what has been confirmed by experts, it can be said that the innovation of this research is to put together two existing theories in the field of social capital and share knowledge and draw relationships between them based on the existing literature. Since in this article we have only mentioned the names of the components of each of the dimensions of the model, in this section the definitions related to them are mentioned (Touboulic \& Walker, 2015).

Table 1. Definitions related to the components of the proposed conceptual framework of this research

\begin{tabular}{|c|c|c|}
\hline $\begin{array}{c}\text { Title } \\
\text { Dimension }\end{array}$ & Component title & Component Description \\
\hline $\begin{array}{c}\text { Structural } \\
\text { dimension of } \\
\text { social capital }\end{array}$ & $\begin{array}{l}\text { Network } \\
\text { configuration }\end{array}$ & $\begin{array}{c}\text { The extent of a person's informal relationships with } \\
\text { different people from different areas of expertise in the } \\
\text { organization }\end{array}$ \\
\hline \multirow{4}{*}{$\begin{array}{l}\text { The relational } \\
\text { dimension of } \\
\text { social capital }\end{array}$} & the trust & $\begin{array}{l}\text { The degree of trust between the sender and receiver of } \\
\text { knowledge }\end{array}$ \\
\hline & Identification & $\begin{array}{l}\text { Existence of a sense of belonging and interest in the } \\
\text { organization in which the person works }\end{array}$ \\
\hline & Friendship & $\begin{array}{l}\text { The degree of strong friendship between the sender and } \\
\text { receiver of knowledge }\end{array}$ \\
\hline & Cooperation & $\begin{array}{l}\text { The degree of strong cooperation between the sender } \\
\text { and receiver of knowledge }\end{array}$ \\
\hline \multirow{3}{*}{$\begin{array}{c}\text { Cognitive } \\
\text { dimension of } \\
\text { social capital }\end{array}$} & common language & $\begin{array}{c}\text { Existence of a common language among the members } \\
\text { of the organization }\end{array}$ \\
\hline & $\begin{array}{l}\text { The norm of } \\
\text { knowledge sharing }\end{array}$ & $\begin{array}{c}\text { Existence of a norm called "knowledge sharing" in the } \\
\text { organization }\end{array}$ \\
\hline & $\begin{array}{l}\text { Acceptance of formal } \\
\text { knowledge sharing } \\
\text { frameworks }\end{array}$ & $\begin{array}{l}\text { Acceptance and use of formal knowledge sharing } \\
\text { frameworks in the organization }\end{array}$ \\
\hline Sender & $\begin{array}{l}\text { Motivation to share } \\
\text { knowledge }\end{array}$ & $\begin{array}{c}\text { The level of desire and desire of the individual to share } \\
\text { knowledge in the organization }\end{array}$ \\
\hline
\end{tabular}




\begin{tabular}{|c|c|c|}
\hline $\begin{array}{c}\text { Title } \\
\text { Dimension }\end{array}$ & Component title & Component Description \\
\hline & $\begin{array}{c}\text { Quantity of shared } \\
\text { knowledge }\end{array}$ & The amount of knowledge shared by the sender \\
\cline { 2 - 3 } & $\begin{array}{c}\text { The quality of shared } \\
\text { knowledge }\end{array}$ & The extent to which the knowledge shared was accurate, \\
timely, accurate, and useful
\end{tabular}

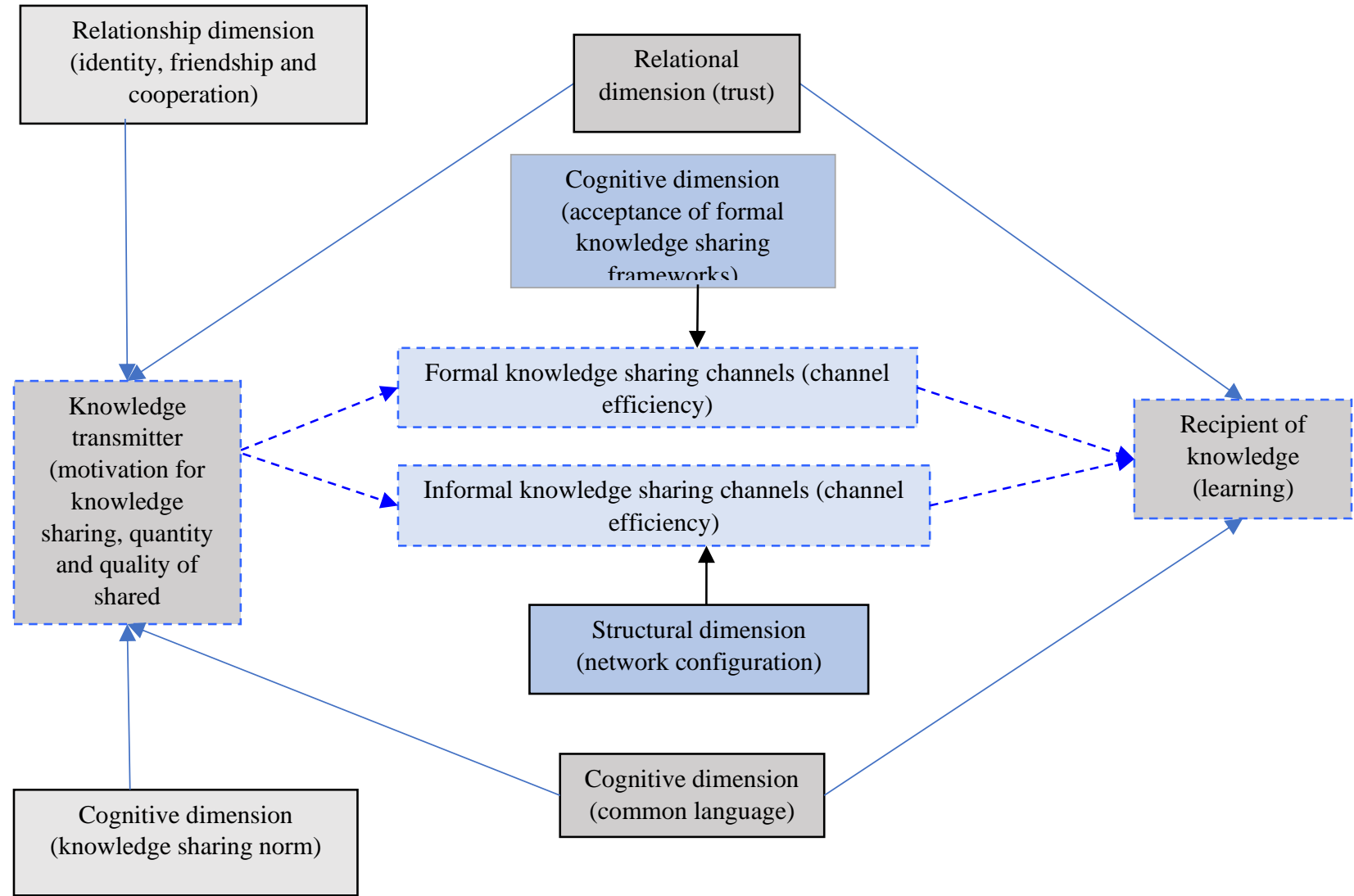

Figure 2. The proposed conceptual framework of this research on the relationship between social capital and knowledge sharing in organizations

\section{Research methodology}

In this research, in order to validate the proposed framework, the brainstorming method and expert panel have been used. A brainstorming and expert panel study involves collecting the opinions of experts several times by repeating the questionnaires repeatedly, to show the convergence of theories and to identify differences of opinion or their divergence. Each repetition forms a period. In fact, the 
questionnaire is a tool for communication and the impact of experts on each other. The steps of implementing the Delphi research method in this research were briefly as follows:

1) Study the literature on the subject and prepare a sound framework before using the brainstorming method and expert panel. Since this step is not part of the brainstorming method and the expert panel is marked with the number zero.

2) Identify the appropriate number of experts and get their approval for participation in the research. The appropriate number of experts according to the texts of the research method should be a number between 10 and 18 people, in this study the number of experts was 12 people.

3) Prepare and send the first round questionnaire.

4) Gathering the opinions of experts, reviewing and analyzing the collected responses and reviewing the conditions for stopping the process. The conditions for stopping the process are one to reach an acceptable agreement (with a minimum of 0.7 for Kendall $\mathrm{W}$ ) and the other is not to change the opinion of the experts after two consecutive rounds and finally the experts' opinion on the necessity of further repetitions (after the third repetition).

5) Prepare and send the next questionnaire and refer to the previous step.

It should be noted that in order to increase the speed of reaching agreement among experts, the interview method was used to complete the questionnaires, which led to the necessary agreement in two rounds on all aspects of the proposed conceptual framework.

\section{Results and discussions}

As mentioned, the number of experts participating in this study was 12 . The statistical index for assessing the degree of agreement in a group is " Kendall's W ". This statistical index, which is related to non-parametric statistics, is used to assess the degree to which a number of evaluators agree on the ranking of several factors. In other words, this index indicates the extent to which the evaluators have acted in the same way in the rank of specific factors. Kendall's W is a number between zero and one, where zero means completely dissimilar opinions and one means completely similar opinions. The research methodology literature states that the number 0.7 is sufficient to indicate the existence of agreement between groups.

The following is how to calculate Kendall's W:

Assume that object $i$ is ranked by judge $j$ and that there are generally $n$ objects and judge $m$. In this case, the total rank given to object $i$ is:

$$
\boldsymbol{R}_{i}=\sum_{j=1}^{m} \boldsymbol{r}_{i, j}
$$

The average value of all rankings is:

$$
\bar{R}=\frac{1}{2} m(n+1)
$$

The sum of the standard deviations, $S$, is defined as follows:

$$
S=\sum_{i=1}^{n}\left(R_{i}-\bar{R}\right)^{2}
$$

Given the above values, the Kendall's $W$ value is calculated as follows:

$$
W=\frac{12 S}{m^{2}\left(n^{3}-n\right)}
$$

It can be assumed that the problem of this research is the ranking of the existence or non-existence of a relationship (as two factors) by experts. In this way, the experts want to express whether in their view the existence of a relationship is in the first place or not. Given that the number 0.7 is set as the minimum appropriate to indicate the existence of convergence and agreement in the group, given the number of 
factors under consideration and the number of elites, at least 11 of the 12 experts must vote for the existence or non-existence of a relationship. The Kendall's W index should not fall below 0.7. The following table summarizes the extent to which experts agree on the relationships identified in the model during the research phase:

Table 2. Summarize the level of expert agreement on the relationships identified in the model during the research stages

\begin{tabular}{|c|c|c|c|c|c|}
\hline \multicolumn{3}{|c|}{ Relationship type } & \multirow{2}{*}{$\begin{array}{c}\text { Type of impact } \\
\begin{array}{c}\text { It has no direct } \\
\text { effect }\end{array}\end{array}$} & \multirow{2}{*}{$\begin{array}{c}\text { Kendall's W in } \\
\text { the first round } \\
\text { of the } \\
\text { questionnaire } \\
1\end{array}$} & \multirow{2}{*}{$\begin{array}{c}\text { Kendall's W } \\
\text { in the second } \\
\text { round of } \\
\text { sending the } \\
\text { questionnaire } \\
-\end{array}$} \\
\hline $\begin{array}{l}\text { Motivation to share } \\
\text { knowledge }\end{array}$ & On & $\begin{array}{c}\text { Network } \\
\text { configuration }\end{array}$ & & & \\
\hline $\begin{array}{l}\text { Motivation to share } \\
\text { knowledge }\end{array}$ & On & the trust & $\begin{array}{c}\text { It has a direct } \\
\text { effect }\end{array}$ & 0.7 & - \\
\hline $\begin{array}{l}\text { Motivation to share } \\
\text { knowledge }\end{array}$ & On & Identification & $\begin{array}{c}\text { It has a direct } \\
\text { effect }\end{array}$ & 1 & - \\
\hline $\begin{array}{l}\text { Motivation to share } \\
\text { knowledge }\end{array}$ & On & Friendship & $\begin{array}{c}\text { It has a direct } \\
\text { effect }\end{array}$ & 0.25 & 1 \\
\hline $\begin{array}{l}\text { Motivation to share } \\
\text { knowledge }\end{array}$ & On & Cooperation & $\begin{array}{c}\text { It has a direct } \\
\text { effect }\end{array}$ & 0.7 & - \\
\hline $\begin{array}{l}\text { Motivation to share } \\
\text { knowledge }\end{array}$ & On & $\begin{array}{l}\text { common } \\
\text { language }\end{array}$ & $\begin{array}{c}\text { It has a direct } \\
\text { effect }\end{array}$ & 0.44 & 1 \\
\hline $\begin{array}{l}\text { Motivation to share } \\
\text { knowledge }\end{array}$ & On & $\begin{array}{l}\text { The norm of } \\
\text { knowledge } \\
\text { sharing }\end{array}$ & $\begin{array}{c}\text { It has a direct } \\
\text { effect }\end{array}$ & 0.7 & - \\
\hline $\begin{array}{l}\text { Motivation to share } \\
\text { knowledge }\end{array}$ & On & $\begin{array}{l}\text { Acceptance of } \\
\text { formal } \\
\text { frameworks }\end{array}$ & $\begin{array}{l}\text { It has no direct } \\
\text { effect }\end{array}$ & 0.44 & 1 \\
\hline Quantity of shared knowledge & On & $\begin{array}{c}\text { Network } \\
\text { configuration }\end{array}$ & $\begin{array}{c}\text { It has no direct } \\
\text { effect }\end{array}$ & 0.44 & 0.7 \\
\hline Quantity of shared knowledge & On & the trust & $\begin{array}{c}\text { It has a direct } \\
\text { effect }\end{array}$ & 0.44 & 1 \\
\hline Quantity of shared knowledge & On & Identification & $\begin{array}{c}\text { It has a direct } \\
\text { effect }\end{array}$ & 0.7 & - \\
\hline Quantity of shared knowledge & On & Friendship & $\begin{array}{c}\text { It has a direct } \\
\text { effect }\end{array}$ & 0.44 & 1 \\
\hline Quantity of shared knowledge & On & Cooperation & $\begin{array}{c}\text { It has a direct } \\
\text { effect }\end{array}$ & 0.7 & - \\
\hline Quantity of shared knowledge & On & $\begin{array}{l}\text { common } \\
\text { language }\end{array}$ & $\begin{array}{c}\text { It has a direct } \\
\text { effect }\end{array}$ & 0.44 & 1 \\
\hline Quantity of shared knowledge & On & $\begin{array}{l}\text { The norm of } \\
\text { knowledge } \\
\text { sharing }\end{array}$ & $\begin{array}{c}\text { It has a direct } \\
\text { effect }\end{array}$ & 0.44 & 1 \\
\hline Quantity of shared knowledge & On & $\begin{array}{l}\text { Acceptance of } \\
\text { formal } \\
\text { frameworks }\end{array}$ & $\begin{array}{l}\text { It has no direct } \\
\text { effect }\end{array}$ & 0.25 & 0.7 \\
\hline
\end{tabular}




\begin{tabular}{|c|c|c|c|c|c|}
\hline \multicolumn{3}{|c|}{ Relationship type } & \multirow{2}{*}{$\begin{array}{c}\text { Type of impact } \\
\begin{array}{c}\text { It has no direct } \\
\text { effect }\end{array}\end{array}$} & \multirow{2}{*}{$\begin{array}{c}\text { Kendall's W in } \\
\text { the first round } \\
\text { of the } \\
\text { questionnaire }\end{array}$} & \multirow{2}{*}{$\begin{array}{c}\text { Kendall's W } \\
\text { in the second } \\
\text { round of } \\
\text { sending the } \\
\text { questionnaire } \\
0.7\end{array}$} \\
\hline $\begin{array}{l}\text { The quality of shared } \\
\text { knowledge }\end{array}$ & On & $\begin{array}{c}\text { Network } \\
\text { configuration }\end{array}$ & & & \\
\hline $\begin{array}{l}\text { The quality of shared } \\
\text { knowledge }\end{array}$ & On & the trust & $\begin{array}{c}\text { It has a direct } \\
\text { effect }\end{array}$ & 1 & - \\
\hline $\begin{array}{l}\text { The quality of shared } \\
\text { knowledge }\end{array}$ & On & Identification & $\begin{array}{c}\text { It has a direct } \\
\text { effect }\end{array}$ & 0.44 & 1 \\
\hline $\begin{array}{l}\text { The quality of shared } \\
\text { knowledge }\end{array}$ & On & Friendship & $\begin{array}{c}\text { It has a direct } \\
\text { effect }\end{array}$ & 0.44 & 1 \\
\hline $\begin{array}{l}\text { The quality of shared } \\
\text { knowledge }\end{array}$ & On & Cooperation & $\begin{array}{c}\text { It has a direct } \\
\text { effect }\end{array}$ & 0.44 & 1 \\
\hline $\begin{array}{l}\text { The quality of shared } \\
\text { knowledge }\end{array}$ & On & $\begin{array}{l}\text { common } \\
\text { language }\end{array}$ & $\begin{array}{c}\text { It has a direct } \\
\text { effect }\end{array}$ & 0.25 & 1 \\
\hline $\begin{array}{l}\text { The quality of shared } \\
\text { knowledge }\end{array}$ & On & $\begin{array}{l}\text { The norm of } \\
\text { knowledge } \\
\text { sharing }\end{array}$ & $\begin{array}{c}\text { It has a direct } \\
\text { effect }\end{array}$ & 0.11 & 1 \\
\hline $\begin{array}{l}\text { The quality of shared } \\
\text { knowledge }\end{array}$ & On & $\begin{array}{l}\text { Acceptance of } \\
\text { formal } \\
\text { frameworks }\end{array}$ & $\begin{array}{c}\text { It has no direct } \\
\text { effect }\end{array}$ & 1 & - \\
\hline Efficiency of official channels & On & $\begin{array}{c}\text { Network } \\
\text { configuration }\end{array}$ & $\begin{array}{l}\text { It has no direct } \\
\text { effect }\end{array}$ & 0.44 & 1 \\
\hline Efficiency of official channels & On & the trust & $\begin{array}{c}\text { It has no direct } \\
\text { effect }\end{array}$ & 0.25 & 1 \\
\hline Efficiency of official channels & On & Identification & $\begin{array}{l}\text { It has no direct } \\
\text { effect }\end{array}$ & 0.25 & 1 \\
\hline Efficiency of official channels & On & Friendship & $\begin{array}{c}\text { It has no direct } \\
\text { effect }\end{array}$ & 0.11 & 1 \\
\hline Efficiency of official channels & On & Cooperation & $\begin{array}{l}\text { It has no direct } \\
\text { effect }\end{array}$ & 0.11 & 0.7 \\
\hline Efficiency of official channels & On & $\begin{array}{l}\text { common } \\
\text { language }\end{array}$ & $\begin{array}{c}\text { It has no direct } \\
\text { effect }\end{array}$ & 0.11 & 1 \\
\hline Efficiency of official channels & On & $\begin{array}{l}\text { The norm of } \\
\text { knowledge } \\
\text { sharing }\end{array}$ & $\begin{array}{l}\text { It has no direct } \\
\text { effect }\end{array}$ & 0.03 & 1 \\
\hline Efficiency of official channels & On & $\begin{array}{l}\text { Acceptance of } \\
\text { formal } \\
\text { frameworks }\end{array}$ & $\begin{array}{c}\text { It has a direct } \\
\text { effect }\end{array}$ & 0.11 & 1 \\
\hline $\begin{array}{l}\text { Efficiency of informal } \\
\text { channels }\end{array}$ & On & $\begin{array}{c}\text { Network } \\
\text { configuration }\end{array}$ & $\begin{array}{c}\text { It has a direct } \\
\text { effect }\end{array}$ & 0.7 & - \\
\hline $\begin{array}{l}\text { Efficiency of informal } \\
\text { channels }\end{array}$ & On & the trust & $\begin{array}{c}\text { It has no direct } \\
\text { effect }\end{array}$ & 0.11 & 0.7 \\
\hline $\begin{array}{l}\text { Efficiency of informal } \\
\text { channels }\end{array}$ & On & Identification & $\begin{array}{c}\text { It has no direct } \\
\text { effect }\end{array}$ & 0.7 & - \\
\hline $\begin{array}{l}\text { Efficiency of informal } \\
\text { channels }\end{array}$ & On & Friendship & $\begin{array}{l}\text { It has no direct } \\
\text { effect }\end{array}$ & 0.11 & 1 \\
\hline
\end{tabular}




\begin{tabular}{|c|c|c|c|c|c|}
\hline \multicolumn{3}{|c|}{ Relationship type } & \multirow{2}{*}{$\begin{array}{c}\text { Type of impact } \\
\begin{array}{c}\text { It has no direct } \\
\text { effect }\end{array}\end{array}$} & \multirow{2}{*}{$\begin{array}{c}\text { Kendall's } W \text { in } \\
\text { the first round } \\
\text { of the } \\
\text { questionnaire }\end{array}$} & \multirow{2}{*}{$\begin{array}{c}\begin{array}{c}\text { Kendall's W } \\
\text { in the second } \\
\text { round of } \\
\text { sending the } \\
\text { questionnaire }\end{array} \\
1\end{array}$} \\
\hline $\begin{array}{l}\text { Efficiency of informal } \\
\text { channels }\end{array}$ & On & Cooperation & & & \\
\hline $\begin{array}{c}\text { Efficiency of informal } \\
\text { channels }\end{array}$ & On & $\begin{array}{l}\text { common } \\
\text { language }\end{array}$ & $\begin{array}{c}\text { It has no direct } \\
\text { effect }\end{array}$ & 0.11 & 0.7 \\
\hline $\begin{array}{l}\text { Efficiency of informal } \\
\text { channels }\end{array}$ & On & $\begin{array}{l}\text { The norm of } \\
\text { knowledge } \\
\text { sharing }\end{array}$ & $\begin{array}{c}\text { It has no direct } \\
\text { effect }\end{array}$ & 0.11 & 1 \\
\hline $\begin{array}{l}\text { Efficiency of informal } \\
\text { channels }\end{array}$ & On & $\begin{array}{l}\text { Acceptance of } \\
\text { formal } \\
\text { frameworks }\end{array}$ & $\begin{array}{c}\text { It has no direct } \\
\text { effect }\end{array}$ & 1 & - \\
\hline Learning in the receiver & On & $\begin{array}{c}\text { Network } \\
\text { configuration }\end{array}$ & $\begin{array}{c}\text { It has no direct } \\
\text { effect }\end{array}$ & 0.7 & - \\
\hline Learning in the receiver & On & the trust & $\begin{array}{c}\text { It has a direct } \\
\text { effect }\end{array}$ & 0.7 & - \\
\hline Learning in the receiver & On & Identification & $\begin{array}{c}\text { It has no direct } \\
\text { effect }\end{array}$ & 0.25 & 1 \\
\hline Learning in the receiver & On & Friendship & $\begin{array}{c}\text { It has no direct } \\
\text { effect }\end{array}$ & 0.11 & 1 \\
\hline Learning in the receiver & On & Cooperation & $\begin{array}{l}\text { It has no direct } \\
\text { effect }\end{array}$ & 0.25 & 1 \\
\hline Learning in the receiver & On & $\begin{array}{l}\text { common } \\
\text { language }\end{array}$ & $\begin{array}{c}\text { It has a direct } \\
\text { effect }\end{array}$ & 0.25 & 1 \\
\hline Learning in the receiver & On & $\begin{array}{l}\text { The norm of } \\
\text { knowledge } \\
\text { sharing }\end{array}$ & $\begin{array}{c}\text { It has no direct } \\
\text { effect }\end{array}$ & 0.44 & 1 \\
\hline Learning in the receiver & On & $\begin{array}{l}\text { Acceptance of } \\
\text { formal } \\
\text { frameworks }\end{array}$ & $\begin{array}{c}\text { It has no direct } \\
\text { effect }\end{array}$ & 0.44 & 1 \\
\hline
\end{tabular}

\section{Conclusion}

The proposed framework of this research shows that the main bottleneck in the knowledge sharing process is the sender. Numerous factors affect the motivation, quantity and quality of knowledge shared by him. The proposed conceptual model shows the factors in the field of social capital well. This means that the managers of the organization should pay special attention to people with knowledge to activate the process of knowledge sharing in the organization as a driving force. The multiplicity of influencing factors sends a message to managers that they need to take a holistic view because underemployment in one of the influencing factors may be able to neutralize all activities performed on other factors.

On the other hand, the proposed conceptual framework distinguishes well between formal and informal channels of knowledge sharing in the organization. Formal channels are controlled and manageable channels. Although the main burden of knowledge sharing in organizations lies with informal channels, the more managers can shift the knowledge shared in the organization to formal channels, the more they can manage the process. This is a part of the job that social capital in particular helps to achieve. The proposed framework discusses the acceptance of the use of formal frameworks. In other words, this framework suggests that in order to increase the efficiency of official channels, individuals in the organization should collectively accept the use of these channels. In other words, in this section, 
managers should focus on the organization as a whole. Perhaps the term can be used to say that the organization should use the norm of using formal knowledge sharing channels.

In addition to trying to increase the efficiency of formal channels, managers should strive to strongly enhance informal knowledge sharing channels. As the conceptual framework of this research suggests, this is done through the development of informal relationships between people in the organization. Many organizations use programs such as celebrations, seminars, and group trips to build these relationships between people in the organization.

\section{Implications of the research}

Recipients of knowledge must be able to understand the knowledge sent by the sender and be sure of its accuracy. Only then, after feeling the need for this knowledge, will they learn it. The proposed conceptual model has clear recommendations for developing trust and common language between the sender and receiver of knowledge. Managers of the organization should try to influence their human resources in terms of professional ethics, increase the trust in the organization and create opportunities for more interaction, especially between people from different fields, to develop a Help common and understandable language among all members of the organization. It is only in the shadow of this common language that one can expect that part of the most difficult types of knowledge in terms of transferability - hidden knowledge - will be able to move between different individuals and units of the organization.

Managers test this model at the level of different organizations and also develop it according to the different categories offered for knowledge - the most recent of which is the division of knowledge into overt, covert and potential knowledge [27/03, 54 and 04/27] are suggested as suitable topics for further research.

\section{References}

Alejandro, T. B., Yang, J., Alejandro, T. G. B., \& Boles, J. S. (2011). The role of social capital and knowledge transfer in selling center performance. Journal of Business \& Industrial Marketing.

Argote, L., \& Fahrenkopf, E. (2016). Knowledge transfer in organizations: the roles of members, tasks, tools, and networks. Organizational Behavior and Human Decision Processes, 136, 146-159.

Bapuji, H., \& Crossan, M. (2005). Co-evolution of social capital and knowledge: an extension of the Nahapiet And Ghoshal (1998) Framework. Paper presented at the Academy of Management Proceedings.

Brauner, E., \& Becker, A. (2006). Beyond knowledge sharing: the management of transactive knowledge systems. Knowledge and Process Management, 13(1), 62-71.

Buonincontri, P., Morvillo, A., Okumus, F., \& van Niekerk, M. (2017). Managing the experience cocreation process in tourism destinations: empirical findings from Naples. Tourism Management, 62, 264-277.

Cleveland, S., \& Ellis, T. J. (2015). Rethinking knowledge sharing barriers: a content analysis of 103 studies. International Journal of Knowledge Management (IJKM), 11(1), 28-51.

Dabić, M., Stojčić, N., Simić, M., Potocan, V., Slavković, M., \& Nedelko, Z. (2020). Intellectual agility and innovation in micro and small businesses: The mediating role of entrepreneurial leadership. Journal of Business Research, 123, 683-695.

De Clercq, D., Dimov, D., \& Thongpapanl, N. (2013). Organizational social capital, formalization, and internal knowledge sharing in entrepreneurial orientation formation. Entrepreneurship Theory and Practice, 37(3), 505-537.

Duan, Y., Wang, W., \& Zhou, W. (2020). The multiple mediation effect of absorptive capacity on the organizational slack and innovation performance of high-tech manufacturing firms: Evidence from Chinese firms. International Journal of Production Economics, 229, 107754.

Fadel, K. J., \& Durcikova, A. (2014). Enhancing the motivation, opportunity, and ability of knowledge workers to participate in knowledge exchange. Paper presented at the 2014 47th Hawaii International Conference on System Sciences.

Fang, Y.-H., \& Chiu, C.-M. (2010). In justice we trust: Exploring knowledge-sharing continuance intentions in virtual communities of practice. Computers in Human Behavior, 26(2), 235-246.

Hajro, A., Gibson, C. B., \& Pudelko, M. (2017). Knowledge exchange processes in multicultural teams: Linking organizational diversity climates to teams' effectiveness. Academy of Management Journal, 60(1), 345-372. 
Isaksen, A., \& Jakobsen, S.-E. (2017). New path development between innovation systems and individual actors. In: Taylor \& Francis.

Jameson, J., Ferrell, G., Kelly, J., Walker, S., \& Ryan, M. (2006). Building trust and shared knowledge in communities of e-learning practice: collaborative leadership in the JISC eLISA and CAMEL lifelong learning projects. British Journal of Educational Technology, 37(6), 949-967.

Jayaram, J., \& Pathak, S. (2013). A holistic view of knowledge integration in collaborative supply chains. International Journal of Production Research, 51(7), 1958-1972.

Kim, W., \& Park, J. (2017). Examining structural relationships between work engagement, organizational procedural justice, knowledge sharing, and innovative work behavior for sustainable organizations. Sustainability, 9(2), 205.

King, W. R., \& Marks Jr, P. V. (2008). Motivating knowledge sharing through a knowledge management system. Omega, 36(1), 131-146.

Levasseur, M., Richard, L., Gauvin, L., \& Raymond, É. (2010). Inventory and analysis of definitions of social participation found in the aging literature: Proposed taxonomy of social activities. Social science \& medicine, 71(12), 2141-2149.

Majchrzak, A., Faraj, S., Kane, G. C., \& Azad, B. (2013). The contradictory influence of social media affordances on online communal knowledge sharing. Journal of Computer-Mediated Communication, 19(1), 38-55.

Mäkelä, K., Andersson, U., \& Seppälä, T. (2012). Interpersonal similarity and knowledge sharing within multinational organizations. International Business Review, 21(3), 439-451.

Maqsood, T., Walker, D., \& Finegan, A. (2007). Extending the "knowledge advantage": creating learning chains. The Learning Organization.

Moustaghfir, K., Schiuma, G., Mura, M., Lettieri, E., Radaelli, G., \& Spiller, N. (2013). Promoting professionals' innovative behaviour through knowledge sharing: the moderating role of social capital. Journal of Knowledge Management.

Nesheim, T., \& Gressgård, L. J. (2014). Knowledge sharing in a complex organization: Antecedents and safety effects. Safety science, 62, 28-36.

Nhon, H. T. (2020). The intellectual capital, firm performance and the moderating role of manager Skills. Business Management and Strategy, 11(2), 1-21.

Oliveira, M., Curado, C., Balle, A. R., \& Kianto, A. (2020). Knowledge sharing, intellectual capital and organizational results in SMES: are they related? Journal of Intellectual Capital.

Paulin, D., \& Suneson, K. (2015). Knowledge transfer, knowledge sharing and knowledge barriersthree blurry terms in KM. Leading Issues in Knowledge Management, 2(2), 73.

Ployhart, R. E., Nyberg, A. J., Reilly, G., \& Maltarich, M. A. (2014). Human capital is dead; long live human capital resources! Journal of management, 40(2), 371-398.

Pyo, M. Y., Kim, J. Y., Sohn, J. O., Lee, E. S., Kim, H. S., Kim, K. O., . . Y Yang, J. R. (2012). The effects of an advanced cardiac life support training via smartphone's simulation application on nurses' knowledge and learning satisfaction. Journal of Korean Clinical Nursing Research, $18(2), 228-238$.

Rass, M., Dumbach, M., Danzinger, F., Bullinger, A. C., \& Moeslein, K. M. (2013). Open innovation and firm performance: the mediating role of social capital. Creativity and innovation management, 22(2), 177-194.

Raza, I., \& Awang, Z. (2020). Knowledge sharing in multicultural organizations: evidence from Pakistan. Higher Education, Skills and Work-Based Learning.

Rosser, S. V. (2005). Through the lenses of feminist theory: Focus on women and information technology. Frontiers: A Journal of Women Studies, 26(1), 1-23.

Simmie, J. (2005). Critical surveys edited by Stephen Roper innovation and space: a critical review of the literature. Regional studies, 39(6), 789-804.

Smedlund, A. (2006). The roles of intermediaries in a regional knowledge system. Journal of Intellectual Capital.

Stone, V., Miller, M. R., Clift, M. J., Elder, A., Mills, N. L., Møller, P., . . Alstrup Jensen, K. (2017). Nanomaterials versus ambient ultrafine particles: an opportunity to exchange toxicology knowledge. Environmental health perspectives, 125(10), 106002.

Touboulic, A., \& Walker, H. (2015). Theories in sustainable supply chain management: a structured literature review. International Journal of Physical Distribution \& Logistics Management.

Vera-Mun oz, S. C., Ho, J. L., \& Chow, C. W. (2006). Enhancing knowledge sharing in public accounting firms. Accounting Horizons, 20(2), 133-155. 
Wang, P., Chaudhry, S., Li, L., Cao, X., Guo, X., Vogel, D., \& Zhang, X. (2016). Exploring the influence of social media on employee work performance. Internet Research.

Wang, W., Sun, J., Liu, C., \& Xue, Z. (2017). Application of immunostimulants in aquaculture: current knowledge and future perspectives. Aquaculture Research, 48(1), 1-23.

Yang, F. X. (2017). Effects of restaurant satisfaction and knowledge sharing motivation on eWOM intentions: the moderating role of technology acceptance factors. Journal of Hospitality \& Tourism Research, 41(1), 93-127.

Zahedi, M. R., \& Khanachah, S. N. (2019). The impact of customer assisted knowledge production capacity on customer capital in a knowledge-based center. Annals of Management and Organization Research, 1(2), 107-121.

Zahedi, M. R., \& Khanachah, S. N. (2020). The effect of knowledge management processes on organizational innovation through intellectual capital development in Iranian industrial organizations. Journal of Science and Technology Policy Management.

Zahedi, M. R., \& Naghdi Khanachah, S. (2019). Measuring the impact of organizational social capital on organizational innovation (Case study: Iran Khodro Industrial Group). 